\title{
Modell und Gegenstand - untrennbar miteinander verbunden
}

\author{
Bernd Ludwig
}

Online publiziert: 8. August 2012

(C) Springer-Verlag 2012

Die Beschäftigung mit der Künstlichen Intelligenz ist ein mühsames Geschäft. Da sich die Themen des Fachgebiets meist an der Grenze zwischen Empirie und systematischer Theorie bewegen, konditionieren sich formale Modelle der Künstlichen Intelligenz und die modellierten Gegenstandsbereich wechselseitig.

Ähnliche Fragen beschäftigen die Bildende Kunst - gerade die Moderne Kunst arbeitet sich an den Wechselwirkungen zwischen Dargestelltem und Darstellungsmitteln sowie Erkenntnisfähigkeit und Ausdrucksmächtigkeit ab und empfindet oft die Mittel und Fähigkeiten des Künstlers als unzulänglich. Gottfried Boehm (Berlin University Press 2007) beschreibt in der Einleitung zu seinem Sammelband ,Wie Bilder Sinn erzeugen - Die Macht des Zeigens“" sehr eindrucksvoll, wie die Entwicklung von Maltechniken, aber auch ganz anderen technischen Entwicklungen wie dem Rasterelektronenmikroskop oder der Magnetresonanztomographie die Bedeutung von Bildern verändern, weil sie - je nach eingesetzter Technik - nicht einfach einen Ausschnitt der beobachteten Welt wiedergeben, sondern weil sie die Interpretation der Welt durch den Betrachter des Bilds beeinflussen.

In analoger Weise beeinflussen die Methoden, Werkzeuge und Verfahren der Künstlichen Intelligenz die Interpretation des Forschers, wie eine theoretische oder anwendungsgetriebene Fragestellung zu beantworten sei. Die große offene Frage dabei ist die Vergleichbarkeit der verschiedenen Vorgehensweisen. In einigen Teilgebieten der Künstlichen Intelligenz, wie zum Beispiel bei Planungsverfahren, haben sich formale Rahmen etabliert (etwa bestimmte Stan- dards von PDDL), innerhalb derer neue Forschungsergebnisse erzielt werden, die dann auch im gegebenen Rahmen vergleichbar bleiben. In anderen Teilgebieten, beispielsweise der automatischen Sprachverarbeitung ist so ein formaler Rahmen kaum in Sicht - wenn man einmal von den artifiziellen sogenannten Kontrollierten Sprachen absieht.

Die Wechselwirkungen zwischen Modell und Modelliertem bleiben bestehen, und es bleibt die Herausforderung an die Forschung, durch neue Sichtweisen auf alte Fragen an dieser Problematik weiter zu arbeiten. Dies gilt auch für Teilgebiete, die sich mit der Mustererkennung überschneiden, allen voran die Frage der Klassifikation von Daten, die Rauschen unterworfen sind. Auch hier wird sich die beschriebene Wechselwirkung nie auflösen lassen.

Daher ist es immer wichtig, sich zu informieren, welche Fortschritte bei der Anwendung schon länger etablierter Verfahren für diese chronisch schwierigen Fragestellungen in der jüngsten Vergangenheit erzielt wurden. Die aktuelle Ausgabe der KI versucht einen Beitrag dazu zu leisten, indem das Thema der Neuronalen Lernverfahren in Hinblick auf jüngste Entwicklungen ausgeleuchtet wird.

Dafür geht ein herzlicher Dank im Namen aller Herausgeber an Barbara Hammer, die eine vielseitige, spannende und abwechslungsreiche Ausgabe über die aktuellen Trends bei Neuronalen Lernverfahren zusammengestellt hat. Allen Leserinnen und Lesern wünsche ich viel Vergnügen bei der Lektüre und viele neue Erkenntnisse, die fruchtbar sind für einen neuen Blick auf offene Fragen.

Bernd Ludwig
B. Ludwig ( $₫)$

LS Informationswissenschaft, Universität Regensburg,

Universitätsstraße 31, 93053 Regensburg, Deutschland

e-mail: Bernd.Ludwig@ sprachlit.uni-regensburg.de 


\section{Planned Main Topics}

\section{Social Media}

Social Media has led to radical paradigm shifts in the ways we communicate, collaborate, consume, and create information. Technology allows virtually anyone to disseminate information to a global audience almost instantaneously. Information published by peers in the form of Tweets, blog posts, or Web documents through online social networking services has proliferated on an unprecedented scale, contributing to an exponentially growing data deluge. A new level of connectedness among peers adds new ways for the consumption of (traditional) media. We are witnessing new forms of collaboration, including the phenomenon of an emergent 'collective intelligence'. This intelligence of crowds can be harnessed in myriad ways, ranging from outsourcing simple, repetitive tasks on Amazon Mechanical Turk, to solving complex challenges such as proving a mathematical theorem creatively and collaboratively.

This call for papers welcomes contributions showing: (1) How to make sense of Social Media data, i.e. how to condense, distill, or integrate highly decentralized and dispersed data resulting from human communication, including sensor-collected data to a meaningful entity or information service, or (2) How Social Media contributes to innovation, collaboration, and collective intelligence. We invite papers covering all aspects of Social Media analysis including Social Media in Business (especially for Marketing, Innovation, and Collaboration), Entertainment (especially Social News, Social Music Services, Social TV, and Social Network Games), as well as Art (e.g. City Installations).

Applications of Social Media in art may be understood as a playing field for translating highly decentralized 'social data' into centralized forms of artful expression, thus furthering our intuitive understanding of these complex emergent phenomena. The list of topics mentioned below is neither exhaustive nor exclusive. Insightful artifacts and methods as well as analytical, conceptual, empirical, and theoretical approaches (using any kind of research method, including experiments, primary data from social media logs, case studies, simulations, surveys, and so on) are within the scope.

The list of topics mentioned below is neither exhaustive nor exclusive. Insightful artifacts and methods as well as analytical, conceptual, empirical, and theoretical approaches (using any kind of research method, including experiments, primary data from social media logs, case studies, simulations, surveys, and so on) are within the scope.

- Information/Web mining (e.g. opinion mining)

- Prognosis (e.g. trend and hot topic identification)

- Collective Intelligence

- Crowdsourcing
- Swarm Creativity, Collaborative Innovation Networks

- (Dynamic) Social Media Monitoring

- Sentiment, Natural Language Processing

- Social Media within and for Smart Cities, Smart Traffic, Smart Energy

- Social Networks for the collaboration of large communities

- User behavior, social interaction

- Social Network Analysis (SNA), semantic network analysis

- Social search engines and aggregators

- Social network games

- Personalization and adaptation to user preference

- Trust, reputation, social control, privacy

- Information reliability, Web spam, content authenticity (e.g., detecting 'astroturfing')

For inquiries and submissions please contact:

Prof. Dr. Detlef Schoder

University of Cologne (Köln)

Department of Information Systems and

Information Management

Pohligstrasse 1

50969 Cologne

Germany

schoder@wim.unikoeln.de

\section{Symbol Grounding}

In robotics and intelligent systems, there is a growing trend to include high level semantic knowledge for enabling better reasoning and increased functionality. One of the most important aspects in integrating is the problem of intrinsically linking the symbols used by a cognitive agent to their corresponding meanings through grounding language in perception and action. This is widely known as the "Symbol Grounding Problem (SGP)" defined by Harnad in 1990, where a linguistic symbol representing a meaning, needs to be grounded in the perceived world. For cognitive agents and robots, a subset of symbol grounding is the anchoring problem which focuses on the connection between symbols and physical object while interacting in the environment. In a multi-robot system, this problem is more challenging as symbols have not only to be grounded, but commonly shared in order to facilitate the exchange of information.

This is called the social grounding problem. This also raises questions with respect to human-robot dialog modeling, where symbols and their references need to be communicated and how the social grounding between robots can be made transparent to a human interaction partner. This special issue includes technical papers, reports on current research projects, interviews, book reviews and others with focus on 
current developments and challenges in Symbol Grounding in intelligent systems.

Topics of interest include but are not limited to:

- Symbol Grounding in intelligent systems

- Social Symbol grounding

- Anchoring symbols to sensor data form physical objects

- Symbol Grounding applied to language acquisition

- Symbol Grounding in robotics and intelligent systems

- AI applications of Symbol Grounding

- Knowledge representation and reasoning for robotics and intelligent systems

- Dialog modeling and Symbol Grounding

Interested authors should contact one of the guest editors to discuss a possible contribution:

Prof. Silvia Coradeschi

AASS, Orebro University

70182 Orebro, Sweden

silvia.coradeschi@oru.se

Docent Amy Loutfi

AASS, Orebro University

70182 Orebro, Sweden

amy.loutfi@oru.se

Dr.-Ing. Britta Wrede

CoR-Lab/Applied Informatics

Bielefeld University

Bielefeld, Germany

bwrede@techfak.uni-bielefeld.de

\section{Space Robotics}

While Space Exploration may be considered anything but dull, it certainly is very dangerous. Expanding our knowledge on the solar system to look for clues to such fundamental questions as the origins of life, or a sustained human presence on anything other than earth may well be worth the risk. The involved costs for mitigating the risk of human space flight are prohibitive. Robotic missions, like the hugely successful Mars Exploration Rovers, have shown that
Robotics as a sub-field of Artificial Intelligence can perform scientific exploration activities without human presence, and will play an even more prominent role in future mission scenarios. Worldwide technology research efforts are continuously expanded the capabilities of mobile robotic systems. This special issue on "Space Robotics" of the Künstliche Intelligenz Journal seeks to present a collection of research efforts, industry activities and other insights into this hugely interesting and versatile field of AI.

The topics of interest include, but are not limited to:

- Exploration systems and technologies

- Orbital servicing

- Human mission support

- Operations support

- System design/architecture/behavior

The Künstliche Intelligenz Journal which is published and indexed by Springer supports the following lists of formats: Technical contributions, research projects, discussions, dissertation abstracts, conference reports and book reviews.

If you are interested in contributing to this special issue, please contact one of the guest editors:

Jakob Schwendner

Robotics Innovation Center

Deutsches Forschungszentrum für Künstliche

Intelligenz (DFKI)

28359 Bremen, Germany

jakob.schwendner@dfki.de

Frank Kirchner

Robotics Innovation Center

Deutsches Forschungszentrum für Künstliche

Intelligenz (DFKI)

28359 Bremen, Germany

frank.kirchner@dfki.de

Bernd Sommer

Deutschen Zentrums für Luft- und Raumfahrt (DLR)

Königswintererstrasse 522-524

53227 Bonn, Germany

Bernd.Sommer@dlr.de 